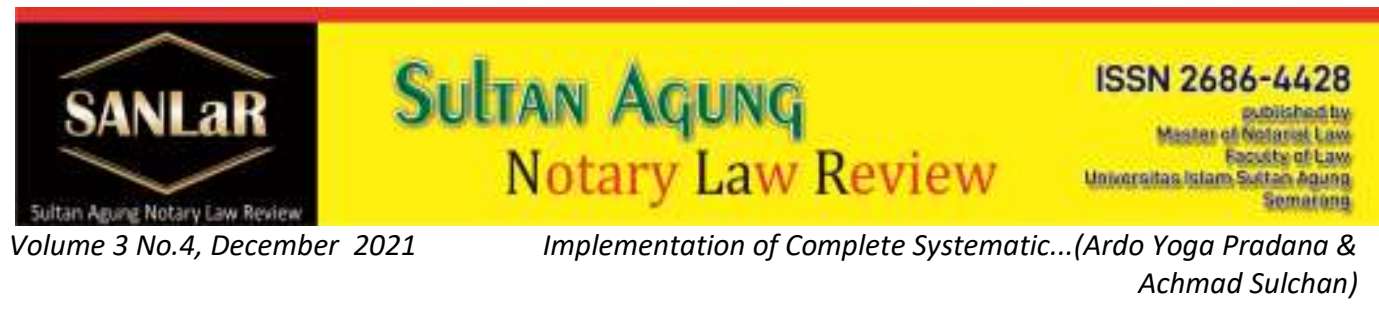

\title{
Implementation of Complete Systematic Land Registration Fee (PTSL) Determination at City/District Level
}

\author{
Ardo Yoga Pradana*) and Achmad Sulchan ${ }^{* *}$ \\ $\left.{ }^{*}\right)$ Faculty of Law, Universitas Islam Sultan Agung (UNISSULA) Semarang, E-mail: \\ ardoyoga12@yahoo.com \\ ${ }^{*}$ ) Faculty of Law, Universitas Islam Sultan Agung (UNISSULA) Semarang, E-mail: \\ ach.sulchan@unissula.ac.id
}

\begin{abstract}
This study aims to examine the policy for setting a Complete Systematic Land Registration (PTSL) fee at the central government level and the implementation of a Complete Systematic Land Registration (PTSL) fee determination at the Regency/City level. The research method in this thesis uses a normative juridical method and the research specification is descriptive analysis with the type of data based on primary and secondary data. Based on the results of observations and studies of laws and regulations related to the object of research, it shows that the PTSL costing policy has been regulated by the central government through a Joint Decree of 3 Ministers in which PTSL costs are categorized according to the region. Local governments in determining policies related to PTSL costing, their implementation must still refer to central policies so that policy synchronization continues. Regions that set costs in accordance with the SKB rules can immediately socialize the implementation of PTSL. Meanwhile, regions that determine the costs of PTSL themselves, through a policy-making mechanism and their determination must be regulated in writing through regional/village regulations. Suggestions from the results of this study. The implementation of PTSL needs to be socialized more massively, the government must ensure that there are no illegal fees, and if there are costs that exceed the provisions, a written determination is made and socialized to the public.
\end{abstract}

Keywords: Fees; Implementation; Land; Registration.

\section{Introduction}

The implementation of registered land throughout Indonesia has encountered various obstacles, both from the government and from the willingness of the 
community to register their land. The results of research conducted by Ardani (2019) found that the biggest obstacle faced by the government was the low participation of the community which was indicated by the lack of community response when the land office officer conducted socialization at the PTSL location, was not at the location when the land measurement was to be carried out, besides that the community also had stigmatized that land registration costs are quite high. ${ }^{1}$

Land registration that can reach all of Indonesia is realized by the government by launching the Complete Systematic Land Registration (PTSL) program. The government has set a target in 2025 that all land in Indonesia has certificates, this target is an acceleration in the issuance of land certificates with a total of about 126 million parcels which if done without acceleration will only be achieved in a period of more than 100 years. ${ }^{2}$ PTSL as a form of government effort can accelerate the land registration process because this program requires various roles from the government which in this case is the Land Office as a committee and also village officials, as well as with support from the community.

Complete Systematic Land Registration (PTSL) is a substitute for the National Agrarian Operations Project (PRONA). In 2016 through the Regulation of the Minister of Agrarian Affairs and Spatial Planning/Head of the National Land Agency Number 35 of 2016 concerning the acceleration of the implementation of Complete Systematic Land Registration (PTSL). PTSL is a simultaneous land registration activity for all land registration objects for the first time. The method used in PTSL simultaneously replaces the method that was previously carried out sporadically. PTSL activities include collecting physical data and juridical data on land registration objects. The realization of this program is the issuance of land certificates. PTSL is an acceleration program that is targeted to be able to complete 79 million land parcels by $2025 .^{3}$

The stipulated regulations explain that the certificate is given free of charge, but in the process of applying and implementing PTSL there must be a fee that must be paid by the community as an applicant. The central government has set standard fees that can be charged to the community. This will be followed up by the district/city government to determine the standard fee to be charged to the applicant. For example, the government of Sanggau Regency, West Kalimantan set the cost of the PTSL program at IDR 250,000. This is stated in a local government regulation which states the amount of costs required in preparation

\footnotetext{
${ }^{1}$ Ardani, M.N. 2019. "Tantangan Pelaksanaan Kegiatan Pendaftaran Tanah Sistematis Lengkap dalam Rangka Mewujudkan Pemberian Kepastian Hukum". Jurnal Gema Keadilan 6 (3).p. 280.

${ }^{2}$ Https://www.atrbpn.go.id/

${ }^{3}$ https://kominfo.go.id/content/detail/12924/program-ptsl-pastikan-penyelesaian-elektronlahan-akan-pertitarget/0/artikel_gpr, accessed 8 April 2021.
} 
for the implementation of PTSL is IDR 250,000 per PTSL participant. ${ }^{4}$ For the Java area, the cost standard set is also different from the area outside Java. In Malang Regency, the cost set for the preparation of PTSL implementation is IDR 150,000 per PTSL participant. Although a standard cost for PTSL preparation has been set for each region, not all regions have set costs in accordance with these regulations. This is revealed in the results of research in the Banyuwangi area where the standard fee is set at IDR $150,000.00$ per PTSL participant but in practice there is still a cost that exceeds the standard in the hamlet of Kedungrejo, Banyuwangi Regency. The fees charged are carried out twice a period according to the number of fees. . In the first period it is IDR 750,000.00 while for the second period it is IDR $450,000.00 .{ }^{5}$ Although there are costs that must be borne by the community, this does not reduce the enthusiasm of the community to participate in this program because these costs are relatively lower than if the community makes their own land certificates.

\section{Research Method}

In carrying out this research, the writer uses the following methodology: The approach method in this research is normative law research. The specifications used in this research are analytical descriptive. The legal materials used in this research are primary legal materials and Secondary Law materials and data analysis techniques conducted in normative legal research.

\section{Results and Discussion}

\subsection{Policy for Determining Complete Systematic Land Registration Fees (PTSL) at the Central Government Level}

Complete systematic land registration (PTSL) is a government program that makes it easier for the community to register their land systematically at a relatively lower cost than if the community did land registration independently. This program has the aim of providing an increase in the welfare and prosperity of the community and the country's economy, as well as an effort to prevent land disputes and conflicts by providing legal certainty as stated in article 2 of the Regulation of the Minister of Agrarian Affairs and Spatial Planning/National Land Agency No. 12 of 2017. Land parcels that can become PTSL objects have been regulated in Article 3 paragraph (2) which states that PTSL objects are all parcels of land without exception, both parcels of land for which there is no land right or parcels of land rights,

\footnotetext{
4 Sangau Regent Regulation Number 5 of 2018 concerning Standard Fees for Complete Systematic Land Registration

${ }^{5}$ Primastya, A.A. 2020. "Pembebanan Biaya Pendaftaran Tanah Sistematis Lengkap (PTSL)

Tinjauan Peraturan Bupati No.11 Tahun 2018 dan Maslahah Mursalah".
} 
As an acceleration program, the central government has made various policies to support the realization of the targets that have been set. The cost of implementing the program has been standardized by the central government and freed up financing for the community. The arrangement of costs and sources of funding that do not use funds from the APBN is regulated in a joint decree of the Minister of Agrarian Affairs and Spatial Planning/Head of the National Land Agency, Minister of Home Affairs, Minister of Villages for Development of Disadvantaged Regions and Transmigration concerning Funding for Preparation for Systematic Land Registration (SKB). The purpose of the issuance of this SKB is as a benchmark in determining the costs of implementing PTSL preparation at the local government level. This Joint Decree needs to be reaffirmed in its implementation at the local government level. In determining the cost of PTSL, local governments must follow the regulations set forth in the SKB. The types of activity budgets mentioned in the SKB are as follows:

a. Document Preparation Activities

The budget specified in the preparation of this document includes the procurement of documents related to the statement letter made by the land owner explaining that the land is not included in the disputed land, history of land ownership, information showing that the land is not owned by the government/village/region. , is not land in the forest area and the land has never been issued a land certificate.

b. Procurement of stakes and stamps

In this activity, the details of the budgeted costs are the procurement of stakes for the boundaries of a plot of land, totaling 3 pieces, and 1 stamp duty which is used to ratify the statement letter.

c. Operational activities of village officers

Activities related to the operations of village officers that have been budgeted for are related to the procurement of supporting documents, transportation of stakes, as well as transportation costs for village officials who travel from the village office to the land office with the aim of document correction.

In addition, the SKB of the three ministers also stated that the Regent/Mayor could budget for the Complete Systematic Land Registration fee that was not accommodated in the APBN and APB of Village, which could be included in the Regional APBD according to the capacity of each region. It aims to provide cost relief to the community. However, not all local governments have the ability to provide cost relief to the community or bear all the costs incurred in the PTSL 
program, therefore there is a need for deliberation in each region to determine the amount of costs that must be borne independently by the community. The central government itself has provided limits that can be used as a reference for local governments in determining the amount of costs borne by the community.

a. For category I which includes the provinces of Papua, West Papua, Maluku, North Maluku, East Nusa Tenggara, a fee of IDR 450,000.00 is charged.

b. For category II which includes the provinces of Riau Islands, Bangka Belitung, Central Sulawesi, North Sulawesi, Southeast Sulawesi, West Nusa Tenggara, a fee of IDR $350,000.00$ is charged.

c. For category III which includes the provinces of Gorontalo, West Sulawesi, South Sulawesi, Central Kalimantan, West Kalimantan, North Sumatra, Aceh, West Sumatra, East Kalimantan, a fee of IDR 350,000.00

d. For category IV which includes the provinces of Riau, Jambi, South Sumatra, Lampung, Bengkulu, South Kalimantan, a fee of IDR 250,000.00 is charged

e. As for the last category, namely category $\mathrm{V}$ which covers the islands of Java and Bali, a fee of IDR 150,000.00 is charged

The costs mentioned above are for a one-time application for certificate registration and do not include the cost of making a deed, Customs for the Acquisition of Land Rights (BPHTB) and Income Tax (PPh), and these costs are borne by the community. ${ }^{6}$

The government has determined sources of funding that can be used to finance PTSL activities. PTSL financing can be obtained from various sources as follows: ${ }^{7}$

a. Funds provided by the Ministry of Agrarian Affairs and Spatial Planning/National Land Agency are in the form of DIPA (Budget Program List) funds with a special budget for PTSL, Prona, transmigration, land redistribution, land reform, and land rights certification programs.

\footnotetext{
6 The Ninth Dictum Joint Decree of the Minister of ATR/BPN, Minister of Home Affairs, Minister of Villages, Development of Disadvantaged Regions and Transmigration, known as SKB 3 (three) Ministers No. 25/SKB/V/2017 concerning Financing for Complete Systematic Land Registration Preparation.

$7 \quad$ Regulation of the Minister of Agrarian and Spatial Planning/Head of the National Land Agency Number 12 of 2017 concerning Acceleration of Complete Systematic Land Registration in All Territories of the Republic of Indonesia in Article 33 paragraphs (1) and (2).
} 
b. DIPA funds provided by ministries or other government agencies.

c. Provincial, Regency/City Regional Revenue and Expenditure Budget (APBD) and Village Funds;

d. Funds from State-Owned Enterprises/Regional-Owned Enterprises, as well as private legal entities through Corporate Social Responsibility (CSR) funds.

e. Funds collected from the community through the activities of the Mass Self-Help Certificate (SMS) which must be adjusted to the provisions of the legislation.

f. Funds from receipt of grants, loans (loans) from private legal entities or in other forms provided through the mechanism of the State Revenue and Expenditure Budget and/or Non-Tax State Revenue.

g. Cooperation carried out with other parties whose acquisition and use can be accounted for in accordance with the laws and regulations.

\subsection{Implementation of Complete Systematic Land Registration Fee (PTSL) Determination at the District/City Local Government Level}

PTSL as the government's priority agenda, is not only the responsibility of the Ministry of Agrarian Affairs and Spatial Planning/National Land Agency (ATR/BN) but also needs support and commitment from local governments. The key to the success of the PTSL program is the support from the local government because the land object is located in the regional area, especially the village, and the community as the owner of the land object is located. Local government activities in the success of this program can be done by bridging between the community and the land office as the main implementer of the PTSL program.

The government has provided convenience to the community regarding PTSL costs, but in determining PTSL costs, local governments must be able to consider various aspects of costs that arise in the program. The central government has provided several categories of nominal fees and types of use of fees with the aim of uniformity of costs at the level of local government. Therefore, local governments need to regulate sources of funding for PTSL programs that are not included in the state budget so that the costs borne by the community are not too high. The local government in this case the Regent/Mayor can take steps in accordance with the minister's direction in helping realize the PTSL program in this case related to the determination of PTSL costs so that they are not burdensome. 
a. Prepare a budget for PTSL registration fees that are not included in the APBN or APBD.

b. Provide relief and reduction of tax costs for the acquisition of land and building rights (BPHTB) to the community receiving the certificate.

c. Provide complete socialization related to PTSL starting from the requirements, the registration process to the issuance of the certificate as well as details of the costs required for PTSL registration.

d. Referring to Article 385 of Act No. 23 of 2014 concerning Regional Government, the Mayor/Regent ordered the regional inspectorate to coordinate with law enforcement officials regarding the implementation of the PTSL program.

Based on the results of research, several local governments have followed up on policies from the central government by making policies related to the determination of PTSL costs in their regions, as follows:

a. Implementation of PTSL Fee Determination in Medaeng Village, Waru District, Sidoarjo Regency

The Sidoarjo Regency Land Office obtained a quota in the implementation of PTSL of 60 thousand certificates with a target of 60 thousand registered land parcels to be completed by the end of the 2020 working period. ${ }^{8}$

The determination of PTSL fees in this area follows the amount of fees that have been set by the government, namely IDR 150,000.00. The details of these costs include stamp duty, boundary marking/palm fees (pipes, fences, short walls), warkah fees and village apparatus transportation costs are borne by the PTSL applicant community. The determination of this fee follows the rules set out in the 3 Ministerial Decree. This area is included in category $V$. The type of activity budget whose costs are determined in accordance with the Decree of the Minister of Madaeng Village, Waru District, Sidoarjo Regency is described as follows:

1) Document Preparation Activities

2) Stakes and Stamps Procurement Activities

3) Operational Activities of Village/Village Officers

The determination of PTSL costs in the village of Madaeng, Waru District, Sidoarjo Regency which has followed the policy of the central government can be

${ }^{8}$ Lika, S. D. R., \& Sholichah, N. (2020). Implementasi Kebijakan PTSL di Desa Madaeng, Kecamatan Waru, Kabupaten Sidoarjo. Journal of Social Politics and Governance, 2 (1).63-72. 
analyzed by the author that policy making is in accordance with the Van Meter and Van Horn theory which consists of 6 indicators, namely standards and policy targets, resources, communication between organization and activity strengthening, characteristics of implementing agents, social, economic and political conditions and disposition of implementors ${ }^{9}$.

Indicators Standards and policy objectives must be clear and measurable. In the implementation of policies carried out in the village of Madaeng, Waru District, Sidoarjo Regency, this indicator has been fulfilled. The results of the study carried out by the authors found that PTSL costing was in accordance with the 3 Ministerial Decree and the implementation of PTSL also referred to the Minister of Agrarian Regulation No.1 of 2017. Communication indicators and activity strengthening have met the theory because the implementation of PTSL costing in Madaeng village, Waru District, Sidoarjo Regency has synchronized between the central government, the Sidoarjo Regency Land Office and village officials, however, there are still obstacles in the community where socialization is not carried out because there are still people who do not follow PTSL with the assumption that PTSL registration fees are expensive. ${ }^{10}$ Successful land registration depends on the willingness and ability of the community to participate in the land registration program. ${ }^{11}$

\section{b. Implementation of PTSL Costing in Semarang Regency}

The results of the author's review of journals written by Putra, Sarjita and Farid (2019) describe the implementation of PTSL costing carried out in Semarang Regency. In determining the amount of the fee, the village government conducts deliberation with the community, which results in the issuance of a Village Regulation (Perdes). This village regulation is used by the village government in the Semarang Regency area to determine the PTSL fee so that it is not considered an illegal levy (extortion). Although the nominal PTSL fee is different from the fee category that has been determined with the central government, this will not be a problem for the community because the resulting policy is not one-way but the result of an agreement with the community. ${ }^{12}$

The determination of PTSL fees through this village regulation as a form of follow-up to the Governor's Circular Letter in the context of setting the land title fee charged to the applicant must be based on the results of deliberation.

\footnotetext{
${ }^{9}$ Subarsono, (2011). Analisis Kebijakan Publik: Konsep, Teori, dan Aplikasi. Yogyakarta: Pustaka Pelajar

${ }^{10} \mathrm{lbid}$

${ }^{11}$ Rakotonarivo, O. S., Jacobsen, J. B., Poudyale, M., \& Rasoamanana, A. (2019). Estimating welfare impacts where property rights are contested: methodological and policy implications. Land Use Policy, p. 71-83.
}

${ }^{12}$ Putra, A. P., Sarjita., \& Farid, A.H. (2019). Peraturan Desa Sebagai Instrumen Pendukung Pelaksanaan Pendaftaran Tanah Sistematis Lengkap . Jurnal Tunas Agraria, 2 (1). 1-20. 
The steps for setting costs through Village Regulations in Semarang Regency are as follows: ${ }^{13}$

1) Identification of budget needs

This identification activity is carried out so that there is no budget overlap between the budget to be determined and the budget that has been determined in the SKB (financing for one similar activity) budgets that have not been mentioned in the SKB are then allocated in the village budget plan.

2) Preparation of the Budget Plan

3) Consultation with the community related to the budget plan that has been prepared. At this deliberation, discussions were held on solutions to funding shortages that were not included in the APBN and Village APB budgets. This deficiency is then taken into consideration which costs will be borne by the community through self-help or levies. The results of the deliberation that have been agreed upon are then used as a reference in determining PTSL costs as outlined in village regulations.

These steps are carried out with the aim that when the PTSL fee charged to the community if it exceeds the nominal set in the SKB, it is not considered an illegal levy because it is in accordance with the agreement. In addition, every levy imposed on the community can be accounted for in its use. This means that the costing carried out in Semarang Regency has also fulfilled the element of transparency.

The author analyzes the results of the study that has been carried out showing that the costing in Semarang Regency has fulfilled the principle of the openbaarheid principle (principle of publicity) in which PTSL information can be reached and known by the public. ${ }^{14}$ The analysis carried out under the umbrella of the theory of policy implementation models according to Van Meter and Van Horn can be explained that the policy of drafting village regulations in determining PTSL costs in Semarang Regency meets the following indicators.

1) In the standard indicators and policy objectives, it is clear that the costing carried out in Semarang Regency is in accordance with the standards set in the SKB with the standard cost requirements needed for PTSL implementation activities at the village level. The policy targets are also clearly stated in the village regulations with the aim of the costs being determined in accordance with the results of deliberation with the community.

2) Inter-organizational communication and activity strengthening Determining the cost of PTSL in Semarang Regency is a form of good communication between related organizations. Organizations involved in costing range from the central organization to the

\footnotetext{
${ }^{13}$ Ibid.

${ }^{14}$ Ibid, 28.
} 
smallest regional organizations. Activities are marked by various activities, starting from the dissemination of directives from the government to cost-setting deliberations.

3) Social, economic and political conditions

Policy implementation will not succeed without the support of the community. The characteristics of the people in Semarang Regency, most of whom already understand the importance of deliberation. The economy of the people in Semarang Regency is relatively better when compared to other Regencies.

4) Implementor's Disposition

The attitude of all stakeholders who play a role in PTSL activities also plays an active role in guarding the implementation of PTSL.

c. Implementation of PTSL Costing in Kuantan Singingi Kabupaten

Complete Systematic Land Registration does not only cover land objects on the island of Java, but to all regions in Indonesia. Kuantan Singingi Regency is one of the regencies in the Riau Archipelago. The implementation of PTSL in this district is in accordance with the policies set by the central government. The determination of PTSL fees in Kuntang Singingi Regency follows the provisions set out in the 3 Ministerial Decree. The nominal cost of PTSL in this Regency is included in category IV with a nominal fee of IDR 250,000.00.

The budget set for the implementation of PTSL in Kuantan Singingi Regency is financed through the APBN, APBD, mass self-help certificates, BUMN/BUMD/Private CSR funds. The main budget for the implementation of PTSL in Singingi Regency in 2017 is financed through DIPA ${ }^{15}$.

The implementation model of costing in Singingi Regency if analyzed using the Van Meter and Van Horn theory as follows:

(1) Policy standards and objectives

Implementation of the costing policy in Singingi Regency is in accordance with established standards. Costing and budgeting standards have been established through technical guidelines that have been prepared. This technical guide aims to regulate the implementation of PTSL and the budget that has been set in

\footnotetext{
${ }^{15}$ Khairi, A. (2018). Implementasi Program Pendaftaran Tanah Sistematis Lengkap (PTSL) di Kabuptan Singing Tahun 2017. JOM Fisip, 5 (2). p. 1-14.
} 
accordance with the target so that each activity can be accounted for.

(2) Inter-organizational communication and activity strengthening

In this aspect, PTSL costing does not require strengthening activities because the costing is in accordance with the 3 Ministerial Decree, so that what is needed in its implementation is communication in the form of socialization to the community.

(3) Implementor's Disposition

The attitude of the implementor in responding to the policies that have been set on the implementation of PTSL in Singingi Regency shows the awareness of the policy implementers. The National Land Agency is assisted by the local village government together to socialize the program in accordance with established policies.

The analysis of legal certainty theory that can be studied on the implementation of PTSL costing in several regions shows that in determining costs, the government has set a standard fee policy charged to PTSL applicants. The set cost standards have been adjusted to the regions that have been grouped. The regional or district government can directly set cost standards as stated in the Ministerial Decree 3 or determine the amount of fees that will be charged to the community in the form of self-help/levies. The nominal fee is determined in accordance with the central government's policy, so the local government can directly disseminate the PTSL program. Whereas, when you have to set your own costs, it is necessary to have a cost-setting mechanism as well as a mechanism in making policies. Examples of implementation carried out in Semarang Regency in determining PTSL cost policies through several procedures. The purpose of setting costs in accordance with existing mechanisms is to avoid illegal levies that can harm the community. Costing policies that are different from those set by the central government must be regulated in writing and set forth in a regional/village regulation while still referring to central policies. The existence of regional/village regulations as technical guidelines in the implementation of PTSL in the field as a form of compliance with the rules in accordance with the principle of legal certainty. ${ }^{16}$

So legal certainty, in the implementation of PTSL costing, legal certainty is obtained when the fees are determined in accordance with central government policies in the 3 Ministerial Decree. Or when it is determined by the regional government itself, it must be stated in a regional/village regulation or technical

\footnotetext{
${ }^{16}$ Ibid, 14
} 
guide. This avoids the occurrence of irregularities committed by unscrupulous government officials and also maintains public trust, and avoids illegal levies.

As for the theory of justice, it shows that the costs that have been determined in accordance with the policy will certainly fulfill the principle of justice because in determining costs there are various considerations and community involvement in determining the amount of costs to be borne. This aspect of justice can also be seen from the benefits obtained by the community from the PTSL program which provides convenience in land certificates and at a lower cost when compared to making certificates which are carried out independently by a notary. The transparent costing mechanism guarantees security and public trust in government programs. A good understanding of the community about the importance of land registration and land ownership patterns is important in the economic and social life of the community. ${ }^{17}$ This is also in line with the results of other studies which state that the land registration program is a form of government protection against the economic conditions of the community. ${ }^{18}$ This is also consistent with the results of a study conducted in Ghana that farmers feel more secure when the land they have inherited from their ancestors has been officially registered by the government with standardized costing so that it is affordable by all groups of people. ${ }^{19}$

The PTSL costing process is carried out with several procedures and involves the aspirations and capabilities of the community, it can be said that the implementation of PTSL costing at the district/city government level is in accordance with the theory of justice. In accordance with the theory of justice set out by Hans Kelsen, that justice is obtained when PTSL fees are implemented legally so that it fulfills the concept of legality that these general regulations are applied to all cases, and these regulations are applied in district/city local governments. The issuance of PTSL land certificates (deeds) is given when all PTSL processes and procedures have been carried out. The issuance of this land certificate will be given to the land owner directly. The following is an example of a land certificate from PTSL:

\footnotetext{
${ }^{17}$ Moroni, S. (2018). Property as a human right and property as a special title. Rediscussing private ownership of land. Land Use Policy, 70. p. 273-280

${ }^{18} \mathrm{Holland}, \mathrm{M}$., et. Al. (2017). Titling land to conserve forests: The case of Cuyabeno Reserve in Ecuador. Global Environmental Change, 44. p. 27-38.

${ }^{19}$ Ghebru, H., \& Lambrecht, I. (2017). Drivers of perceived land tenure (in)security: Empirical evidence from Ghana. Land Use Policy, 66, p. 293-303.
} 


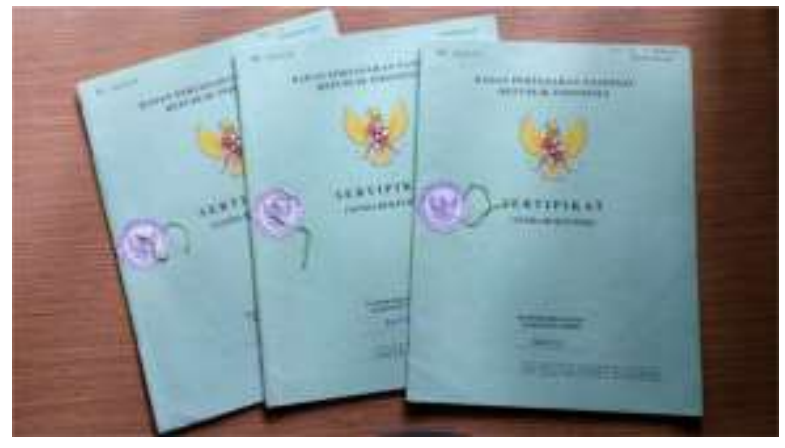

Figure 3.1 Example of PTSL Land Certificate

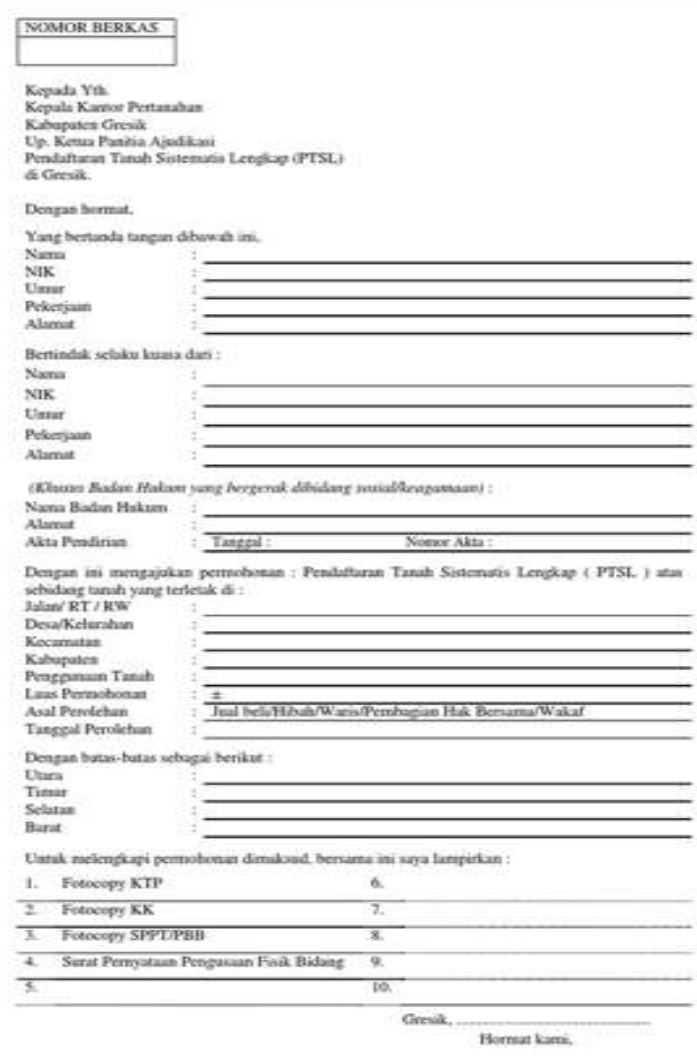

Figure 3.2 PTSL Application Form

\section{Conclusion}

The PTSL costing policy has been regulated by the central government through a Joint Decree of 3 Ministers in which PTSL fees are categorized according to the region. The policy rules provide an opportunity for local governments to 
determine the PTSL budget according to the capabilities of each region. Local governments in determining policies related to PTSL costing, their implementation must still refer to central policies so that policy synchronization continues. For regions that set costs in accordance with the rules of the SKB, they can immediately conduct socialization on the implementation of PTSL. Meanwhile, regions that set their own PTSL costs must go through a policymaking mechanism and their determination must be regulated in writing through regional/village regulations. The implementation of PTSL needs to be socialized more massively, especially related to the costs that will be borne by the applicant and the details of the costs used for whatever so that the public gets certainty of costs and a sense of calm with the nominal fees that have been known, the Government must ensure that there are no illegal levies and ensure that the costing is in accordance with with the policy mechanism that has been established and if there are costs that exceed the provisions, a written determination is made and socialized to the public so that there are no misunderstandings.

\section{References}

Journals:

[1] Ardani, M.N. 2019. "Tantangan Pelaksanaan Kegiatan Pendaftaran Tanah Sistematis Lengkap dalam Rangka Mewujudkan Pemberian Kepastian Hukum". Jurnal Gema Keadilan 6 (3).

[2] Lika, S. D. R., \& Sholichah, N. (2020). Implementasi Kebijakan PTSL di Desa Madaeng, Kecamatan Waru, Kabupaten Sidoarjo. Journal of Social Politics and Governance, 2 (1).

[3] Putra, A. P., Sarjita., \& Farid, A.H. (2019). Peraturan Desa Sebagai Instrumen Pendukung Pelaksanaan Pendaftaran Tanah Sistematis Lengkap . Jurnal Tunas Agraria, 2 (1).

[4] Rakotonarivo, O. S., Jacobsen, J. B., Poudyale, M., \& Rasoamanana, A. (2019). Estimating welfare impacts where property rights are contested: methodological and policy implications. Land Use Policy, 70.

[5] Subarsono, (2011). Analisis Kebijakan Publik: Konsep, Teori, dan Aplikasi. Yogyakarta: Pustaka Pelajar

Books:

[1] Ghebru, H., \& Lambrecht, I. (2017). Drivers of perceived land tenure (in)security: Empirical evidence from Ghana. Land Use Policy, 66.

[2] Holland, M., et. Al. (2017). Titling land to conserve forests: The case of Cuyabeno Reserve in Ecuador. Global Environmental Change, 44.

[3] Khairi, A. (2018). Implementasi Program Pendaftaran Tanah Sistematis Lengkap (PTSL) di Kabuptan Singing Tahun 2017. JOM Fisip, 5 (2). 
[4] Moroni, S. (2018). Property as a human right and property as a special title. Rediscussing private ownership of land. Land Use Policy, 70.

[5] Primastya, A.A. 2020. "Pembebanan Biaya Pendaftaran Tanah Sistematis Lengkap (PTSL) Tinjauan Peraturan Bupati No.11 Tahun 2018 dan Maslahah Mursalah".

Internet:

[1] https://kominfo.go.id/content/detail/12924/program-ptsl-pastikanpenyelesaian-sertifikasi-lahan-akan-sesuaitarget/0/artikel_gpr, accessed on 8 April 2021.

[2] https://www.atrbpn.go.id/, accessed on 9 April 2021.

Regulation:

Sangau Regent Regulation Number 5 of 2018 concerning Standard Fees for Complete Systematic Land Registration 